\title{
»LADIES AND GENTELMEN, ALL ABOARD!« TRAVELLING IN THE NORTHERN ADRIATIC UNTIL THE SECOND WORLD WAR
}

\author{
METOD Š U L I G O J - LJUDMILA S I N K O V I Č
}

\begin{abstract}
ŠULIGOJ, Metod - SINKOVIČ, Ljudmila. "Ladies and gentelmen,all aboard!" Travelling in the northern Adriadic until the Second world war. Historický časopis, 2018, roč. 66, č. 4, pp. 629-648. Bratislava.

The article presents the forms of travelling characteristic of the northern Adriatic that formerly belonged to a unified but multicultural area from the Congress of Vienna in 1815 until 1941. The article focusses on the travelling of the local population and tourists by maritime transport services (the Austrian Lloyd founded in 1836 was the largest transport company of the Habsburg Monarchy) and the railway, and later by road motor transport. According to the available sources (the printed tourist guides are an important source for studying tourism development), we also explained the institutional support for tourism development and strategic development aspects by the Austro-Hungarian and later the Italian (fascist) government. The latter achieved significantly lower results in Istrian tourism due to anti-Slavic actions and other political circumstances, economic depression and the spread of epidemic diseases.

Key words: History of tourism. Northern Adriatic. Transport. Travel. Printed tourist guides. Special interest tourism.
\end{abstract}

DOI: https://doi.org/10.31577/histcaso.2018.66.4.3

\section{Introduction}

The Austro-Hungarian crown-land The Austrian Littoral (Österreichisches Küstenland/Litorale Austriaco/Avstrijsko primorje) with Trieste as free imperial city and state port influenced greatly the development of the coastal part of northern Istria and the southeastern part of the Bay of Trieste. The surrounding towns, such as Novigrad/Cittanova, Umag/Umago, Koper/Capodistria, Izola/Isola d'Istria and Piran/Pirano, ethnically mostly Italian (the Slovenes and Croats mainly populated the rural areas), became lively commercial centres under the influence of Trieste, getting their agricultural supplies from the hinterland of Istria, the Brkini and the Karst (Kras/Carso) region, and their fish, molluses and crabs from the Adriatic. Consequently, as early as the 15th century different entertainment events took place here for the patron saints' days or other important days (holidays, commemorative days) as well as business events (trade fairs) with among 
others a strong presence of foreign participants. ${ }^{1,2}$ As early as that period one can already trace travellers doing their journeys across the continent without any travel guides or with the help of older travelogues pursuing different goals (education, research, culture, religion, adventurism, etc.). The littoral towns are more or less mentioned only as nice viewpoints from a ship, Trieste or Socerb. ${ }^{3}$

In the 19th century those events were mostly linked to the excursions made by the wealthy bourgeoisie and aristocracy. From 1828 there is an organized boat trip from Trieste to Pula/Pola; Francesco Ongaro mentions in his Viaggetto nell' Istria an organized boat trip in 1838; there are written sources about a similar excursion from 1840 (Gita a Pola con battello a vapore). All this proves that there had been organized trips even before the Austrian Lloyd established a regular excursion steamboat line from Trieste to the towns on the western coast of Istria. ${ }^{4,5}$ (see also Figure 1). On 22 June 1851, St. Nazaire's day, the Austrian Lloyd organized transportation to Koper/Capodistria by a steamboat. At the end of the 19th century, the steamboat transported people from the neighbouring towns to Koper/Capodistria to celebrate the town's patron saint. ${ }^{6}$ By 1895 as many as 1150 passengers were transported. It can be assumed that this number was growing in the following years as Il Piccolo on 19 June 1899 reports that as many as 20 steamboats arrived in Koper/Capodistria. Faster and more accessible transport connections (see Fig. 3) accelerated the flow of information and the appearance of the first printed tourist guides. Those books contained a short historical outline, descriptions of natural and cultural sights, tips for local excursions, a list of accommodation possibilities, timetables and prices of the local means of transport (trains and steamboats). Sometimes they also featured commercial ads for

1 MUŽENIČ, Matej. Šagre in ljudski prazniki v severni Istri od 16. do 19. stoletja. In PANJEK, Aleksander, Istrski praznik: preteklost, sedanjost, avtentičnost. Šagre in ljudski prazniki v severni Istri. Koper: Univerza na Primorskem, Znanstveno-raziskovalno središče, Univerzitetna založba Annales, 2012, p. 29-30. ISBN 9789616862073.

2 The major problem of these events was very poor sanitary conditions. For this reason many of them had to be cancelled which consequently brought about a sharp decline in the 19th century. In MUŽENIČ, Šagre in ljudski prazniki v severni Istri od 16. do 19. stoletja, ref. 1, p. 36-37.

3 More can be found in KAVREČIČ, Petra. Pričevalci preteklosti avanturisti in drugi popotniki na Krasu in v Istri pred modernim turizmom. In Acta Histriae, 2011, vol. 19, no. 4, p. 683-702. ISSN 1318-0185.

4 BLAŽEVIĆ, Ivan. Povijest turizma Istre i Kvarnera. Opatija: Otokar Kerševani, 1987, p. 35. ISBN 8638500556.

5 More can be found in ANTIĆ, Vinko. Pomorstvo i naš turizam. In NOVAK, Grga MAŠTROVIĆ, Vjekoslav. Pomorski zbornik. Povodom 20-godišnjice dana mornarice i pomorstva Jugoslavije 1942-1962. Zadar: Institut za historijske i ekonomske nauke, 1962, p. 987-1058.

6 More can be found in BLAŽEVIĆ, Povijest turizma Istre i Kvarnera, ref. 4, p. 38, 47. 
hotels and inns. Maps were an important part of the travel guides. By order of the Austrian Lloyd in 1845, Giuseppe Rieger drew a panorama of the coast of Istria from Trieste to Premantura/Promontore. ${ }^{7}$ The map had in the first line a maritime character but could also be used for tourist purposes. Fabiani ${ }^{8}$ states the examples of good (tourist) maps by Joseph Lavallé and Louis François Cassaso from the beginning of the 19th century. However, at that time most of the traffic still moved on land ${ }^{9}$ - the trip from Koper/Capodistria to Trieste lasted two hours on land and one hour by sea. ${ }^{10}$ The steamboats sailed mostly to Piran/Pirano or even further to Pula/Pola or Rijeka/Fiume. Trieste became a dominant port for cargo and passenger traffic. ${ }^{11}$

On the occasion of the 180th anniversary of the Austrian Lloyd the paper shows how passengers, tourists and local people travelled in the northern part of Istria in the period from the beginning of modern (organized) tourism in the region until the year 1941. We shall concentrate on the period when Opatija/ Abbazia was becoming one of the central tourist destinations of Austria/Austro-Hungarian Monarchy (although Opatija/Abbazia geographically does not belong to the region considered here) until the beginning of WWII that marks a turning point in the development of Istria (especially concerning the socio-political changes). The focus of the paper is on the period when Istria was ruled entirely by the Habsburgs (after the Vienna Congress of 1815) and on the period of the rule of the Kingdom of Italy when Istria was part of a unified multicultural region. Based on the available archival material and research of other authors, the

7 RIEGER, Giuseppe. In Istria e in Dalmazia con il Lloyd Austriaco: itinerario di un viaggio marittimo tra Trieste e Cattaro. Udine: Del Bianco editore, 1977; BLAŽEVIĆ, Povijest turizma Istre i Kvarnera, ref. 4, p. 42; BRESSAN, Marina (Ed.). Signori, si parte! Come viaggiavamo nella Mitteleuropa 1815-1915. Mariano del Friuli: Edizioni della Laguna, 2011, p. 19. ISBN 8883453514.

8 FABIANI, Rossella. "Davanti ai nostri occhi si susseguiva un bell paesaggio dietro l'altro". Massimiliano d'Asburgo viaggiatore. In BRESSAN, Marina. Signori, si parte! Come viaggiavamo nella Mitteleuropa 1815-1915. Mariano del Friuli: Edizioni della Laguna, 2011, p. 67-76. ISBN 8883453514.

9 Although visiting of the hinterland could be very romantic, the question of travel safety anyhow occurred, in BRESSAN, Signori, si parte! Come viaggiavamo nella Mitteleuropa 1815 1915 , ref. 7.

10 CONTENTO, Ugo. Pirano: i bagni d'acqua madre e quelli di spiaggia. Pirano: Direzione dello Stabilimento Balneare, 1892; GABRŠČEK, Andrej. Ročni kažipot po Goriškem, Trstu in Istri in koledar za navadno leto 1902. Let. 8. Gorica: Goriška tiskarna, 1902; BENESCH, Fritz. Verkehrsbuch österreichischer Eisenbahnen: 6. Krain und Küstenland. Wien V: Verlag von Christoph Reisser's Söhne, 1910, p. 65.

11 PEJDO, Tomislav. Politika Austrije (Austro-Ugarske) prema brodarstvu Dalmacije od 1850. do 1880. godine, Radovi Zavoda za povijesne znanosti HAZU u Zadru, 2008, No. 50, p. 275 287. ISSN 1848-8943. Antić claims, that Austria was falling behind with the development of steamboats. In ANTIĆ, „Pomorstvo i naš turizam“, ref. 5, p. 993. 
purpose of the paper is to show analytically different ways of travelling and its organization, highlighting the tourism-related travelling in the northern Adriatic.

\section{Travelling in northern Istria until WWI}

Tourism development in northern Istria was followed by the development of some recognizable destinations in the northern Adriatic such as Opatija/Abbazia, Grado, Mali Lošinj/Lussinpiccolo. ${ }^{12}$ The first passengers were mainly residents of towns or villages from the interior who sold their crops in Trieste; tourists were few. In the years of the establishment of Opatija/Abbazia as a tourist destination (after 1840), the number of passengers on ships or boats travelling as tourists and excursionists increased (especially in the warmer period of the year). When Portorož/Portorose was declared a health resort by the state law of the Ministry of the Interior on 25 July $1897^{13}$, it became worth visiting it by boat since there was also a passenger port - one such excursion is shown in Fig. 1 (excursion by boat from Portorož/Portorose to Grado, 1912). Later, between the two world wars the excursions were a real fad. ${ }^{14}$

Before the Great War, profitable local transport was carried out by different companies, among them the following should be mentioned: ${ }^{15}$ (a) Pietro Viezzoli from Piran/Pirano was the first ship owner in Istria (his business later inherited by his son Antonio), who in 1874 bought his first steamboat named Piranese, in 1876 he had the steamboat named Istriano built in Koper/Capodistria. It operated the line Piran/Pirano - Izola/Isola d'Istria - Trieste; (b) Società Cittadina di Navigazione a Vapore Capodistria, established 1881 and renamed Capodistriano in 1910. After the annexation to Italy Capodistriana was renamed the Società Capodistriana di Navigazione, and operated until 1958. In 1914 the company

12 REHAR, Radivoj. Nastanek in razvoj turizma ob slovenski obali. In LEBEN, France - VILHAR, Srečko - REHAR, Radivoj - SLAVEC Emanuel. Slovenski pomorski zbornik. Koper: Klub pomorščakov v Kopru, 1962, p. 171-178.

13 BRGLEZ, Alja et al., Portorož. Zgodovina turizma in Hotela Palace. Ljubljana: Inštitut za civilizacijo in kulturo, 2005, p. 18; KAVREČIČ, Petra. Parni stroj in turizem na Primorskem. Prometne povezave kot dejavnik turističnega razvoja na primeru Postojne in Portoroža do prve svetovne vojne. In Annales. Series historia et sociologia, 2007, vol. 17, No. 2, p. 315 336. ISSN 1408-5348; KAVREČIČ, Petra. Biseri avstrijske riviere: Opatija, Gradež, Portorož. Začetki modernega turizma na severnem Jadranu. In Kronika, 2009, vol. 57, p. 113-128. ISSN 0023-4923; BLAŽEVIĆ, Povijest turizma Istre i Kvarnera, ref. 4, 94, 97; GOMBAČ, Srečko - BREZOVEC, Tomi. Letala s sidrom. Hidroavioni v Portorožu in okolici. Ljubljana: Tehniška založba Slovenije, 2007, p. 44. ISBN 9789612510527; ANTIĆ, „Pomorstvo i naš turizam“, ref. 5, p. 1008.

14 LAMUT, Mitja. Parniki Jadrana na razglednicah. Zagreb: VBZ Zagreb, 2013, p. 25-26. ISBN 978-953-304-607-5.

15 LAMUT, Parniki Jadrana na razglednicah, ref. 14, p. 11-15, 50, 54, 133; KAVREČIČ, Parni stroj in turizem na Primorskem, ref. 13, 326. 
with its ships carried out the so called "tram traffic" among Koper/Capodistria, Ankaran/Ancarano, Valdoltra and Trieste; (c) Società di Navigazione a Vapore Istria - Trieste with its seat in Trieste, founded in 1886 by Alesandro Cesare, dominated the Istrian lines traffic.

Figure 1: Excursionists on boat, 6 August $1912^{16}$

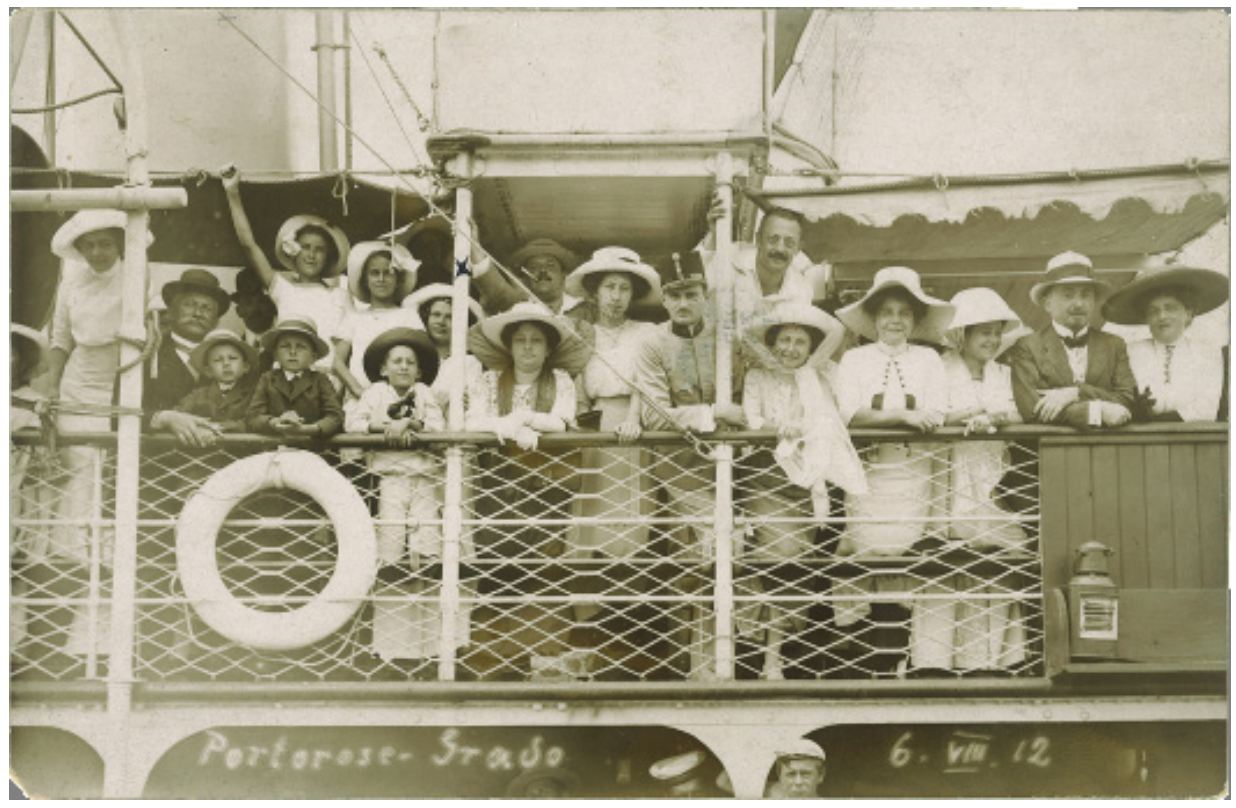

On the coast of northern and western Istria passengers and cargo were also transported by other carriers with their seat in Trieste, Monfalcone and Muggia, and other small shipping companies. ${ }^{17}$ On the other hand, the biggest shipping company in the Austrian and Austro-Hungarian period was the above-mentioned Austrian Lloyd, founded on 2 August 1836. Except in the very beginning, the Austrian Lloyd was not significantly involved in the local traffic. This enabled the development and mergers of small shipping companies in Istria. ${ }^{18}$ They

16 Private collection of Tomi Brezovec, Portorož, Slovenia.

17 More can be found in MEDVEŠČEK, Vladimir. Razvoj potniške obalne plovbe ob vzhodnem Jadranu. In LEBEN, France - VILHAR, Srečko - REHAR, Radivoj - SLAVEC Emanuel. Slovenski pomorski zbornik. Koper: Klub pomorščakov v Kopru, 1962, p. 139-51 and LAMUT, Parniki Jadrana na razglednicah, ref. 14.

18 LAMUT, Parniki Jadrana na razglednicah, ref. 14, p. 11-15; ANTIĆ, Pomorstvo i naš turizam, ref. 5, p. 988, 989. Northern Istria did not fall behind the developed maritime regions and countries at all - more can be found in PEJDO, Politika Austrije (Austro-Ugarske) prema brodarstvu Dalmacije od 1850. do 1880. godine, ref. 11. 
connected the towns several times a day, ${ }^{19}$ the journey from Trieste to Koper/ Capodistria took 45 minutes, to Izola/Isola d'Istria 50 minutes, to Piran/Pirano one hour. ${ }^{20}$ Besides the regular lines, excursionists also arrived at Piran/Pirano ${ }^{21}$ by special lines offering a rich experience including a warm welcome by brass band music in Portorož/Portorose, as in August 1868, when three Lloyd ships (Austria, Nettuno and Ismail) brought around 1,000 daily guests from Trieste to Piran/Pirano and Portorož/Portorose, the locals organized a party with dance music until midnight when the ships returned to Trieste. ${ }^{22}$ On the occasion of the »economic exhibition « in Trieste in September and October 1871, entertainment and sports events took place and excursions were organized to nearby places of interests: on 25th September an excursion Trieste - Muggia - Piran/Pirano was organised. ${ }^{23}$ Porters, couriers and carriers (omnibus, ${ }^{24}$ waggons) were waiting for the passengers to take them to the baths. The prices depended on the type and length of service. ${ }^{25}$

In 1876 the publishing house Baedeker published the guidebook Südbaiern, Tirol und Salzburg, Steiermark, Kärnten, Krain und Küstenland. Handbuch für Reisende, where the coastal towns are mentioned on several-day-voyages by the steamship of the Austrian Lloyd from Trieste to Pula/Pola, Rijeka/Fiume

19 CONTENTO, Pirano: i bagni d'acqua madre e quelli di spiaggia, ref. 10; GABRŠČEK, Ročni kažipot po Goriškem, Trstu in Istri in koledar za navadno leto 1902, ref. 10; Trieste e l'Istria. Trieste: La federazione per il promovimento del concorso di forestieri Stabilimento artistico tipografico G. Caprin, 1912, p. 48.

20 BENESCH, Verkehrsbuch österreichischer Eisenbahnen: 6. Krain und Küstenland, ref. 10, p. 65; Trieste e l'Istria, ref. 19, p. 49-52.

21 BENESCH, Verkehrsbuch österreichischer Eisenbahnen, 6. Krain und Küstenland, ref. 10, p. 66; KAVREČIČ, Parni stroj in turizem na Primorskem, ref. 13.

22 Da una domenica all'altra, Egida, Giornale commerciale, industriale, agricolo e politico, 17th July 1904; Nuova Societa Citt. Di Navigazione a Vapore fra Capodistria-Trieste, Egida, Giornale commerciale, industriale, agricolo e politico, 10th July 1904.

23 BLAŽEVIĆ, Povijest turizma Istre i Kvarnera, ref. 4, p. 47, 49. Other tours offered at the turn of the century are also mentioned there.

24 From 1912, the passengers could take an omnibus with 15 seats and 10 standing places. Due to the unpaved roads the ride was slow and uncomfortable, KAVREČIČ, Parni stroj in turizem na Primorskem, ref. 13, p. 324.

25 More can be found in CONTENTO, Pirano: i bagni d'acqua madre e quelli di spiaggia, ref. 10; Illustrierter Führer durch Dalmatien. Wien, Leipzig: A. Hartleben's Verlag, 1912, p. 28-30; Die Oesterreichiche Riviera. Hotel und Pensionsliste der Kurorte der Ost Riviera, Herausgegeben vom Landesverband für Fremdenverkehr im Ostküstenland Sitz Abbazia 1912/1913. Wien III: Kunstdruckerei Freisch, April 1912, p. 64-65. The porter charged for baggage transportation in the town 40 cents and 1.20 crown to Portorož/Portorose. The transportation fee for a suitcase from the pier to the Tartini Square was 60 cents for a small suitcase, 80 cents for a large or two small; cart transportation: one piece 90 cents, two pieces 1 crown and three pieces 1.50 crown, Trieste e l'Istria, ref. 19, p. 50-51. 
and further to Dalmatia. The coastal towns are mostly described from the sea perspective; the olive groves and hilly Istrian coast stand out. In addition, an example of a one-day excursion by the steamer from Trieste to the northern Istrian coastal towns from Valdoltra/ Valle d'Oltra to Portorož/Portorose should be highlighted as well:

"Departure very early by ship from Muggia and then over the hill (from the top a wonderful view) to Oltre (1 hour), by boat to Capo d'Istria, Roman Justinopolis, an old town with 7.539 inhabitants, situated on an island connected to the mainland by a stone embankment. The cathedral, Palazzo pubblico and saltpans are worth visiting. Then on foot (1 hour) along the sea through Semedela to Izola/Isola d'Istria (good Refosco wine) and on foot to Piran/Pirano (2 hours). From Piran/Pirano 40 minute-walk to the resort of San Lorenzo with fine buildings in a beautiful park. In the evening return to Trieste by steamer... "26

In 1876 the Giustinopoli ran between Koper/Capodistria and Trieste every day three times a day, including holidays. Children had $50 \%$ discount. ${ }^{27}$ The cathedral and the town hall of Koper/Capodistria were very interesting to visitors, the points of interest also included the towns of Piran/Pirano and the baths in Portorož/Portorose. ${ }^{28}$ Portorož/Portorose was also accessible by a tramway operating from 1912 until 1953 between the Piazza Maggiore ${ }^{29}$ in Piran/Pirano to the railway station in Santa Lucia. ${ }^{30}$ The towns of Izola/Isola d'Istria, ${ }^{31}$ Strunjan/ Strugnano and Valle d $\mathrm{Oltra}^{32},{ }^{33}$ attracted excursionists as well. Those places were accessible by sea, by road and by railway. It is worth mentioning the $\mathrm{Pa}$ renzana, the Istrian narrow gauge railway, which from 1 April 1902 connected Trieste to Buje/Buie; later the same year, on 15 December, the line was extended to Poreč/Parenzo. ${ }^{34}$ In the brochure Trieste e l'Istria the railway connection was also advertised for tourism (excursion) purposes. The price higher than the price

26 BAEDEKER, Karl. Südbaiern, Tirol und Salzburg, Steiermark, Kärnten, Krain und Küstenland. Handbuch für Reisende. Leipzig: Baedeker, 1876, p. 401.

27 BLAŽEVIĆ, Povijest turizma Istre $i$ Kvarnera, ref. 4, p. 52.

28 BENESCH, Verkehrsbuch österreichischer Eisenbahnen: 6. Krain und Küstenland, ref. 10, p. 66 .

29 Today named Tartini square.

30 More can be found in KAVREČIČ, Petra. Turizem v Avstrijskem Primorju: zdravilišča, kopališča in kraške jame (1819-1914). Koper: Založba Univerze na Primorskem, 2017. ISBN 9789617023008.

31 It is known that the Society for public events (Società per i pubblici divertimenti) was responsible for the events in Izola in 1912, Trieste e l'Istria, ref. 19, p. 49.

32 Today named Valdoltra.

33 Trieste e l'Istria, ref. 19, p. 49-52; BLAŽEVIĆ, Povijest turizma Istre i Kvarnera, ref. 4, p. 170.

34 KAVREČIČ, Parni stroj in turizem na Primorskem, ref. 13, p. 324. 
of a steamship and the slowness were its disadvantages: $:^{35}$ the ride from Trieste to Izola took one hour and 25 minutes, to Santa Lucia as long as two hours. Porters and guides were available at the stations. The railway line Vienna - Ljubljana - Trieste ${ }^{36}$ constructed in 1857 , undoubtedly had even greater influence on the development of Istrian tourism. It enabled wealthy guests from the continental part of the Austro-Hungarian Monarchy to reach the coast quickly.

An additional offer in Portorož/Portorose was the possibility to rent a boat for up to three persons for the price of one crown per hour. For the wealthier, who travelled in their own car, a garage next to Villa San Lorenzo was available; there were garages also in Koper/Capodistria. The gasoline stations were available to the visitors in Portorož/Portorose, Piran/Pirano and Koper/Capodistria. ${ }^{37}$ According to Kavrečič the road network was rather problematic, disorderly and in bad condition; accidents and robberies were frequent ${ }^{38}$. It should be pointed out that the road infrastructure during the major part of the 20th century lagged behind the transport conditions in the developed world. Motoring circular tours such as (a) Trieste - Muggia - Koper/Capodistria - Piran/Pirano - Buje/Buie, (b) Opatija/Abbazia - Pazin/Pisino - Buje/Buie - Piran/Pirano and (c) Opatija/Abbazia - Učka/Monte Maggiore, Buzet/ Pinguente, Koper/Capodistria were available for tourists. ${ }^{39}$ Furlani ${ }^{40}$ and Baxa ${ }^{41}$ describe in their guidebooks numerous halfday, full-day or two-day excursions from Portorož/Portorose to central Istria or other coastal towns and to the Karst (Kras/Carso). The visitors can walk, take a train or a steamboat or drive by car. The information point was the Spa Commission Office (German Kanzleien der Kurkomission), ${ }^{42}$ where all information about local events was available. In both guidebooks practical information about

35 More can be found in KAVREČIČ, Parni stroj in turizem na Primorskem, ref. 13.

36 BLAŽEVIĆ, Povijest turizma Istre i Kvarnera, ref. 4, p. 44-45; PAVLIČ, Ivo. Promet in turizem. In Turistični vestnik, 1955, vol. 3, No. 9-10, p. 428-430.

37 Trieste e l'Istria, ref. 19, p. 21, 52; BAXA, Carlo. Führer durch Portorose, mit Situationsplan und zahlreichen Abbildungen. Trieste: Buch- und Kunstdruckerei L. Herrmanstoreer, 1914, p. 21.

38 KAVREČIČ́, Turizem v Avstrijskem Primorju: zdravilišča, kopališča in kraške jame (18191914). Koper: Založba Univerze na Primorskem, ref. 30.

39 Die Oesterreichische Riviera. Hotel- und Pensionsliste der Kurorte der Ost Riviera, Herausgegeben vom Landesverband für Fremdenverkehr im Ostküstenland Sitz Abbazia 1912/1913, p. 88, private collection of Tomi Brezovec; BAXA, Führer durch Portorose, mit Situationsplan und zahlreichen Abbildungen, ref. 37, p. 19-20.

40 FURLANI, E. Fürer durch Pirano und Portorose. Trieste; Capodistria: Gius. Stokel \& Debarba - Trieste. Tip. Carlo Priora - Capodistria, 1910.

41 FURLANI, Führer durch Portorose, ref. 40, p. 14-19, 21, 22, 31-32.

42 Opening hours on weekdays: 9 am -12 am and $3 \mathrm{pm}-5 \mathrm{pm}$. More can be found also in GOMBAČ - BREZOVEC, Letala s sidrom. Hidroavioni v Portorožu in okolici, ref. 13 and BLAŽEVIĆ, Povijest turizma Istre i Kvarnera, ref. 4. 
pharmacies, banks, exchange offices, restaurants and other facilities that were obviously an important element of the tourist offer were obtainable. The comprehensive Baedeker ${ }^{43}$ guide covering northern Istria was widely appreciated. It described the type and quality of the offer, prices, routes, train and steamboat schedules etc.; it was obvious that the comprehensive tourist offer was extraordinary. ${ }^{44}$ Worth mentioning is also the Woerl guidebook from 1913, pointing out the tourist agent - Reiseagentour Francesco Comisso - with its seat on the square opposite the Spa Commission Office, ${ }^{45}$ which offered many services to tourists. This also applied to travel agents in Trieste which offered information and sold the local train tickets.

The opening of the Palace Hotel in $1910^{46}$ caused a significant increase of the number of tourist visiting Portorož/Portorose. This was the result of the growing demand for accommodation facilities of higher standard as most of the guests were nobles, wealthier citizens and military or naval officers on holiday and convalescence. The Information Office (Italian $L$ 'ufficio d'informazioni), established by the Provincial Association for the Promotion of Foreign Tourism Development in Trieste and Istria (Italian Federazione provinciale per il promovimento del concorso di forestieri a Trieste e nell 'Istria) on 2 April 1910 in Trieste and managed by Joseph Strandner, played a part in promoting the area. The office maintained contacts with 360 tourist agencies around the world independently or in cooperation with Austrian Lloyd ${ }^{47}$ The tourists in Portorož/Portorose were coming from the homeland, other Austrian crown lands, Hungarian lands, the former Bosnia and Herzegovina, other Balkan countries, Germany, Italy, France, England, Russia and other European countries and from North America. ${ }^{48}$ The

43 BAEDEKER, Karl. Südbaiern, Tirol und Salzburg, Steiermark, Kärnten, Krain und Küstenland. Handbuch für Reisende, ref. 26; BRESSAN, Signori, si parte! Come viaggiavamo nella Mitteleuropa 1815-1915, ref. 7 and KAVREČIČ, Parni stroj in turizem na Primorskem, ref. 13.

44 BRGLEZ, Portorož. Zgodovina turizma in Hotela Palace, ref. 13, p. 22-23; KAVREČIČ, Parni stroj in turizem na Primorskem, ref. 13, p. 328; PUCER, Albero. Portorož-100 let organiziranega turizma. Sprehod skozi čas. Katalog k razstavi Pokrajinskega arhiva Koper. Koper: Pokrajinski arhiv, 1985.

45 WOERL, Leo. Woerl's Reisehandbücher. Illustrierter Führer durch Portorose-Pirano und Umgebung sowie Anleitung zu Ausflügen durch ganz Istrien. Leipzig: Woerl`s Reisebücherverlag, 1913.

46 The year 1910 was of great importance due to the foundation of the Company for the regulation of the town as a climatic health resort in Strunjan/Strugnano, which was mainly focused on the construction of a seaport, coastal path between Strunjan/Strugnano and Portorož/Portorose, and the connection of both places by a cableway, BLAŽEVIĆ, Povijest turizma Istre i Kvarnera, ref. 4, p. 142, 143.

47 BLAŽEVIĆ, Povijest turizma Istre i Kvarnera, ref. 4, p. 135.

48 PUCER, Portorož-100 let organiziranega turizma. Sprehod skozi čas, ref 44. 
expansive destination development that had not yet reached the results of Opatija/Abbazia and Grado, was brutally interrupted by WWI ${ }^{49}$ influencing Portorož/ Portorose and the whole of northern Istria indirectly. However, already in 1914 (so called Italian front opened in 1915) some of the first civilian victims in this part of Europe had fallen. ${ }^{50}$

On 13 August 1914, the Austrian Lloyd steamer Baron Gautsch by mistake came across a minefield of the Austrian Navy near Rovinj/Rovigno on the return trip of its traditional line Trieste-Kotor-Trieste and sank with the majority of its passengers. During the war the infrastructure was not damaged, because this area of Istria was not in the front line (the Isonzo front which touched the sea to the north of Monfalcone ${ }^{51}$ and aerial attacks on Pula/Pola ${ }^{52}$ were far away), but the tourism facilities were used for recovery and treatment of soldiers and officers. ${ }^{53}$ According to the secret Treaty of London the territory became a part of the Kingdom of Italy after the First World War. ${ }^{54}$

49 KAVREČIČ́, Parni stroj in turizem na Primorskem, ref. 13, p. 328; KAVREČ IČ, Biseri avstrijske riviere: Opatija, Gradež, Portorož., ref 13; BRGLEZ, Portorož. Zgodovina turizma in Hotela Palace, ref. 13; GOMBAČ - BREZOVEC, Letala s sidrom. Hidroavioni v Portorožu in okolici, ref. 13, p. 45.

50 The first civilian victim of WWI in The Austrian Littoral was countess Lucy Christalnigg who was shot on 10 August 1914 at a checkpoint in Srpenica (Isonzo valley), in CRISTIANINI, Nello. L'ultima estate: Lucy Chritalnigg, prima vittima civile della Prima Guerra Mondiale. In Isonzo, 2014, vol. 26, No. 103, p. 32-33. ISSN 1124-6510; SVOLJŠAK, Petra. Soška fronta. Ljubljana: Cankarjeva založba, 1994. ISBN 8636108683.

51 More about this in ŠULIGOJ, Metod. Impact of the Great War on the conditions for the development of the hospitality industry in Gorizia/Görz/Gorica and its surroundings. In Historický časopis, 2016, Vol. 64, No. 3, p. 431-450. ISSN 0018-2575 and MORSCHER, Christine - GALVIN, Ray. Alice Schalek's War. The story of Austria-Hungary's only woman War correspondent in the First World War, 2006. Just Solution, Ray Galvin's website. (the work is accessible on-line: Http://justsolutions.eu/Resources/AliceSchaleksWar.pdf) [cit. 2016-6- 2]

52 More about this in BAČIĆ, Vilim, A. Poviest Prvog svjetskog rata na Jadranu - I. Dio. Zagreb: Izdanje hrvatskog izdavalačkog bibliografskog zavoda, 1945 and MARSETIČ, Raul. Analisi dell'apparato militare austro-ungarico a Pola durante la Prima guerra mondiale. In Atti, 2012, Vol. XLII, No. 1, p. 483-520. ISSN 0392-9493.

53 More about this in GOMBAČ - BREZOVEC, Letala s sidrom. Hidroavioni v Portorožu in okolici, ref. 13, p. 45.

54 ŠIŠIĆ, Ferdo. Jadransko pitanje na Konferenciji mira u u Parizu. Zbirka Akata i dokumenta. Zagreb: Matica Hrvatska,1920, p. 134; see also DIKLIĆ, Marjan. Zadar i Rapallski ugovor (Uz 90. obljetnicu). In Radovi Zavoda za povijesne znanosti HAZU u Zadru, 2011, No. 53, p. 223-242. ISSN 1848-8943; REITER, Sanja. Ribolovno razgraničenje između Kraljevine Srba, Hrvata i Slovenaca i Kraljevine Italije kroz prizmu Brijunske konvencije o ribolovu iz 1921. godine. In Radovi Zavoda za povijesne znanosti HAZU u Zadru, 2015, No. 57, p. 297316. ISSN 1848-8943; LIPUŠČEK, Uroš. Sacro egoismo: Slovenci v krempljih tajnega londonskega pakta 1915. Ljubljana: Cankarjeva založba, 2012. p. 512. ISBN 9789612318710. 


\section{The period between WWI and WWII}

Post-war Istria as a tourist destination appears in the guidebooks to Trieste in Italy as a romantic landscape. ${ }^{55}$ In the medieval towns with narrow streets and Venetian architecture it seems as if time has stopped. ${ }^{56}$ There was a lack of investment interest in the tourist resort Portorož/Portorose or other north Istrian destinations in favour of the numerous Italian seaside resorts. As a result, the traditional industries including tourism began to stagnate. ${ }^{57}$ However, guests were still travelling by regular ships and trains. After the establishment of better road connections the transport by cars and buses in the 1920s and 1930s became more popular. The guidebooks gave information about recommended car tours, road conditions, petrol stations and garages. In terms of tourism Istria had to cope with new strong competition from Italian tourist destinations presenting new economic circumstances for Istrian tourism. Significant changes took place mainly in terms of ownership of business entities that were owned largely by the Germans and Austrians before the war. Italians obviously favoured the Italian guests and developed tourism on the northern Adriatic coast (Grado, Venice)..$^{58}$ The guests were mostly Italians and in $192190.5 \%$ came from Friuli Venezia Giulia. ${ }^{59}$ The guidebooks from this period largely emphasized the Italian culture and identity of the area by reference to well-known personalities from the period of the Venetian domination and by stressing the Venetian architecture in the northern Istrian towns. However, the Bertarelli ${ }^{60}$ guidebook includes a glossary of Venetian, Friulian, Slovenian, Croatian and German useful vocabulary to

55 WOERL, L. Woerl's Reisebücher, Illustrierter Führer von Triest und Umgebung. Leipzig: Woerl's Reisebücher-Verlag, 1925, p. 79; Guida illustrata descrittiva della citta di Trieste principali localita e Grotte della Venezia Giulia. Trieste: Precisa, 1925, p. 135-138; BAEDEKER, Karl. Dalmatien und die Adria (Westliches Südslawien-Bosnien-Budapest-Istrien-Albanien-Korfu). Handbuch für Reisende. Leipzig: Baedeker, 1929, p. 139-146; Guida di Trieste e della Venezia Giulia. Trieste: Stabilimento tipografico nazionale, 1937, p. 83.

56 Illustrirter Führer durch Triest und Nachbarstätten. Trieste: Verlag Peterlin, 1925, p. 90.

57 TREBŠE-ŠTOLFA, Milica. Razvoj turizma na območju Pokrajinskega arhiva Koper do ukinitve koprskega okraja v luči upravno-teritorialnih sprememb. In BONIN Zdenka - RADULOVIČ, Branko. Arhivsko gradivo s področja turizma in turistične dejavnosti. Uporabnik in arhivsko gradivo: zbornik referatov / XVII. posvetovanje Arhivskega društva Slovenije, Koper, 23. do 25. oktober 1996. Ljubljana: Arhivsko društvo Slovenije, 1996, p. 12-18. ISBN 9616143042; A. BRGLEZ, Portorož. Zgodovina turizma in Hotela Palace, ref. 13, p. 19; GOMBAČ - BREZOVEC, Letala s sidrom. Hidroavioni v Portorožu in okolici, ref. 13. p. 46; REHAR, Nastanek in razvoj turizma ob slovenski obali, ref. 12, p. 173.

58 OLO, Piran. Kratek oris razvoja turistične dejavnosti v občini Piran. In Občinski ljudski odbor Piran, 1958. Private collection of Tomi Brezovec.

59 BLAŽEVIĆ, Povijest turizma Istre i Kvarnera, ref. 4, p. 193.

60 BERTARELLI, L.V. Guida d'Italia del Touring Club Italiano: Le tre Venezie. Terzo Volume. Milano: Touring Club Italiano, 1925, p. 8, 253-257, 290-296. 
facilitate communication when travelling. The first detailed maps of the coastal towns with marked sights were also added.

One of the few investors in tourism was the Cosulich family from Trieste (originating from Lošinj, Croatia), mainly engaged in shipping. By purchasing the company Portorose in 1919 and transferring the company's seat from Vienna to Trieste, it took over the management of the Palace Hotel and then invested money in buying some other hotels, which means that they became the driving force of coastal tourism. ${ }^{61}$ The guidebook Portorose names all representatives of the Cosulich Company in Italy, Austria, Germany and Bohemia providing information about hotels in Portorož/Portorose. ${ }^{62}$ This also applies to the guidebook Portorose presso Trieste Bagni di mare e d'acqua madre from 1926, ${ }^{63}$ where even more European cities with Cosulich representatives are listed. The guidebook $L$ 'acqua salso-bromo-jodica di Portorose: bagni di acqua madre: irrigazioni - inalazioni: polverizzazioni-fanghi: opuscolo per i medici $(1926)^{64}$ states the Cosulich representatives in Italy and directs the guests to get information about hotels by directly addressing the Società per Azioni Portorose in Portorož/ Portorose (Trieste). Moreover, it also mentions that their agencies provide information, make reservations and payments free of charge. The Bax guidebook from $1920^{65}$ describes many of the opportunities for one or more day excursions, mentioned already in its first issue in 1914. The additional offer primarily attracted the wealthier population. Thus in 1921 the Cosulich family purchased a hydroplane of type FBA and built a hydroplane landing area in the Bernardin Gulf (Portorož/Portorose). ${ }^{66}$ The Cosulich Company first organized panoramic excursions and quick transport to Trieste, Pula/Pola and Venice. The fleet was enlarged and in 1922 the airline S.I.S.A. (Societa Italiana Servizi Aeronautici)

61 GOMBAČ - BREZOVEC, Letala s sidrom. Hidroavioni v Portorožu in okolici, ref. 13, p. 45; BRGLEZ, Portorož. Zgodovina turizma in Hotela Palace, ref. 13. p. 39; D'AGOSTINO, Carlo - TOMARCHIO, Mario. La prima compagnia aerea commerciale italiana. Udine: Aviani \& Aviani Editori, 2007. ISBN 9788877721143.

62 Portorose. Capodistria: Stabilimento tipografico nazionale Carlo Priora, s.a.

63 Portorose presso Trieste. Bagni di mare e d'acqua madre. Capodistria: Stabilimento tipografico nazionale Carlo Priora, 1926.

64 L'acqua salso-bromo-jodica di Portorose: bagni di acqua madre : irrigazioni - inalazioni: polverizzazioni - fangh : opuscolo per i medici. Portorose: Stabilimento di cure di Portorose, 1926, p. 29-32.

65 BAXA, Carlo. Guida di Portorose presso Trieste. Capodistria: Stabilimento tipografico nazionale Carlo Priora, 1920.

66 Istarska enciklopedija, Zračni promet. Leksikografski zavod Miroslav Krleža (the work is accessible on-line: http://istra.lzmk.hr/clanak.aspx?id=3110) [cit. 2015-8-16]; Airport PulaRazvoj zračne luke, Pula airport, (the work is accessible on-line: http://www.airport-pula.hr/ default.aspx?id=26) [cit. 2015-8-16; D’AGOSTINO - TOMARCHIO, La prima compagnia aerea commerciale italiana, ref. 61. 
was established, which eventually ${ }^{67}$ provided a permanent hydroplane connection with eastern (coastal) and northern parts of the Kingdom of Italy - see Figure 2 showing the airline connections, distances and duration of flights. ${ }^{68}$ In addition, Austrian industrialist Karl Kupelwieser, who in order to enrich the tourist offer of the Brijuni islands, bought the hydroplane »I Pola« and established a civil aviation connection with Trieste, Ancona and Opatija/Abbazia ${ }^{69}$ Because of the increasing needs, a floating pier for the passengers and hangars for parking and repairing the planes were constructed in the Bernardin Gulf. After the foundation of the pilot's school in 1923 the first pilot candidates came to Portorožl Portorose. ${ }^{70}$

Figure 2: Airline connections of the S.I.S.A. company ${ }^{71}$

\begin{tabular}{|c|c|c|c|c|}
\hline \multicolumn{5}{|c|}{ Distanze principali e tempi medi di volo } \\
\hline \multirow{2}{*}{ PERCORSI } & $\begin{array}{c}\text { Distanzia } \\
\text { parziale }\end{array}$ & $\begin{array}{l}\text { Tempo } \\
\text { medlo } \\
\text { impleg. }\end{array}$ & \begin{tabular}{|c|} 
Distanza \\
progres- \\
siva
\end{tabular} & $\begin{array}{l}\text { Terripo } \\
\text { progregs } \\
\text { sivo }\end{array}$ \\
\hline & $\mathrm{km}$. & $\overline{\substack{\text { minuti } \\
\text { primi }}}$ & $\mathrm{km}$. & $\begin{array}{c}\mathrm{h}=\text { oro } \\
\text { m minuti } \\
\text { prtmi }\end{array}$ \\
\hline Trieste - Grado & 30 & 12 & 30 & $12 \mathrm{~m}$ \\
\hline Grado - Venczia & 85 & 45 & 115 & $57 \mathrm{~m}$ \\
\hline Venezia - Chioggia & 25 & 10 & 140 & Ih $7 \mathrm{~m}$ \\
\hline Chioggia - Ostiglia & 110 & 50 & 250 & ih $57 \mathrm{~m}$ \\
\hline Ostiglia - Casalmaggiore & 65 & 25 & 315 & $2 \mathrm{~h} 22 \mathrm{~m}$ \\
\hline Casalmaggiore - Cremona & 45 & 20 & 360 & $2 \mathrm{~h} 44 \mathrm{~m}$ \\
\hline Cremona - Placenza & 30 & 12 & 390 & $2 \mathrm{~h} 56 \mathrm{~m}$ \\
\hline Piacenza - Pavia & 55 & 23 & 445 & $3 \mathrm{~h} 19 \mathrm{~m}$ \\
\hline Pavia - Torino & 132 & 55 & 577 & 4h $14 \mathrm{~m}$ \\
\hline Pavia - Genova & 125 & 50 & 570 & 4h $9 m$ \\
\hline Trieste - Pola & 103 & 45 & 103 & $45 \mathrm{~m}$ \\
\hline Pola - Lussino & 69 & 30 & 172 & 1h $15 \mathrm{~m}$ \\
\hline Lussino - Zara & 80 & 35 & 252 & $1 \mathrm{~h} 50 \mathrm{~m}$ \\
\hline Trieste - Portorose & 25 & 10 & 25 & $10 \mathrm{~m}$ \\
\hline Trieste - Brioni & 100 & 45 & 100 & $45 \mathrm{~m}$ \\
\hline Brioni - Fiume & 110 & 45 & 210 & in $30 \mathrm{~m}$ \\
\hline Fiume - Lussino & 100 & 45 & 310 & $2 \mathrm{~h} 15 \mathrm{~m}$ \\
\hline Lussino - Zara & 80 & 40 & 390 & $2 \mathrm{~h} 55 \mathrm{~m}$ \\
\hline Trieste - Fiume & 140 & in & 140 & Ih \\
\hline Fiume - Brioni & 110 & $50 \mathrm{~m}$ & 250 & Ih $50 \mathrm{~m}$ \\
\hline Brioni - Venezia & 150 & in $10 \mathrm{mr}$ & 400 & $3 \mathrm{~h}$ \\
\hline
\end{tabular}

67 It actually started to operate in 1926.

68 Additional lines to the south (e.g. Durrës in Albania) and west (e.g. Marseille) should be mentioned as well.

69 Istarska enciklopedija, Zračni promet, ref. 66; Airport Pula-Razvoj zračne luke, ref. 66; D'AGOSTINO - TOMARCHIO, La prima compagnia aerea commerciale italiana, ref. 61.

70 GOMBAČ - BREZOVEC, Letala s sidrom. Hidroavioni v Portorožu in okolici, ref. 13, p. 47-51; BRGLEZ, Portorož. Zgodovina turizma in Hotela Palace, ref. 13, p. 39; BLAŽEVIĆ, Povijest turizma Istre i Kvarnera, ref. 4, p. 205; LAMARCHE, Paul E. Mussolini Pilots, Italy. In Popular Aviaton and Aeronautics, May 1929; D'AGOSTINO - TOMARCHIO, La prima compagnia aerea commerciale italiana, ref. 61.

71 Cartina delle linee aeree. Bergamo: Istituto Italiano d'arti grafiche di Bergamo, s.a. Private collection of Tomi Brezovec. 
The steamer transport after WWI did not stop, new connections and new shipping companies appeared (the north Adriatic was known for its strong competition between local/regional shipping transport). Due to the economic crises, some of them were forced to sell their ships or to merge with bigger and stronger transport companies. ${ }^{72}$ On 25 November 1922, the (fascist) regime's favourite newspaper L'Istria redenta published an advertisement with the timetable of the company Società Capodistriana di Navigazione, operating the line Koper/ Capodistria-Trieste and Koper/Capodistria-Valdoltra/Valle d'Oltra several times daily. The timetable for working days differed from that on holidays. ${ }^{73}$ Similarly there is an advertisement of the same company with the winter timetable not significantly different from the previously mentioned; timetables were also published in Le vie dell Istria by Ubald Bottizer ${ }^{74}$ from March 1928. The bus company Stefano Muzi from Šmarje near Koper/Capodistria has published there the timetable of the line Koper/Capodistria-Novigrad/Cittanova and Koper/Capodistria-Šmarje on weekdays and Sundays. The publication also contains steamboat and bus timetables. ${ }^{75}$ Hence, the Parenzana's timetable was advertised in newspapers, such as the above mentioned L'Istria redenta from 9 December 1922, where the timetable valid from the beginning of the month ${ }^{76}$ was published. Due to the lack of profitability the Parenzana stopped operating after 33 years on 31 August 1935 and was replaced by a bus service operating four times daily. However, the significant ship, aircraft, road and railway links from that period are shown on the map (see Figure 3) from the tourist brochure Portorose, Thermen-Strandbäder.

The Italian Tourist Board in its guidebook Guida pratica di luoghi di soggiorno e cura d'Italia from 1933 describes the coastal towns of northern Istria and lists all the travel options. The content does not differ significantly from the previously mentioned. The two newly established shipping companies Compagnia di Navigazione Adriatica from Venice and Navigazione Schiavon from

72 MEDVEŠČEK, Razvoj potniške obalne plovbe ob vzhodnem Jadranu, ref. 17, p. 144-148.

73 Orario dei piroscafi della Società Capodistriana di Navigazione. L'Istria redenta, $25^{\text {th }}$ November 1922, p. 4.

74 BOTTIZER, Ubaldo (Ed.). Le vie dell'Istria. Pubblicazione Turistico-Colturale. Capodistria: s.n., 1928.

75 In the preface the editor Bottizer addresses the Istrians and highlights the need for such a tourist-cultural publication. In addition to the tourist publicity, Istrian history and the beauties of Portorož/Portorose and regional places of interest are covered. In the spirit of the time, the publication also praises fascism in Istria and other political issues. Rehar states that encouraging Italian guests to visit Istria also had nationalistic purposes, in REHAR, Nastanek in razvoj turizma ob slovenski obali, ref. 12, p. 175.

76 Orario della Ferrovia Trieste-Parenzo, valevole dal $1^{\circ}$ Dicembre 1922. L'Istria redenta, 9 December 1922, p. 4. 
Trieste offered their services. ${ }^{77}$ The information points listed in the guidebook should be indicated specifically: in Portorož/Portorose the visitors can obtain information at the Independent health agency (Italian Azienda autonoma di cura), in Piran/Pirano in the town hall, in Izola at the Association for the Promotion of Foreign Tourism (Italian Società per il Promovimento dei Forestieri) established in $1931 .{ }^{78}$

Figure 3: Transport connections in Istria in $1938^{79}$

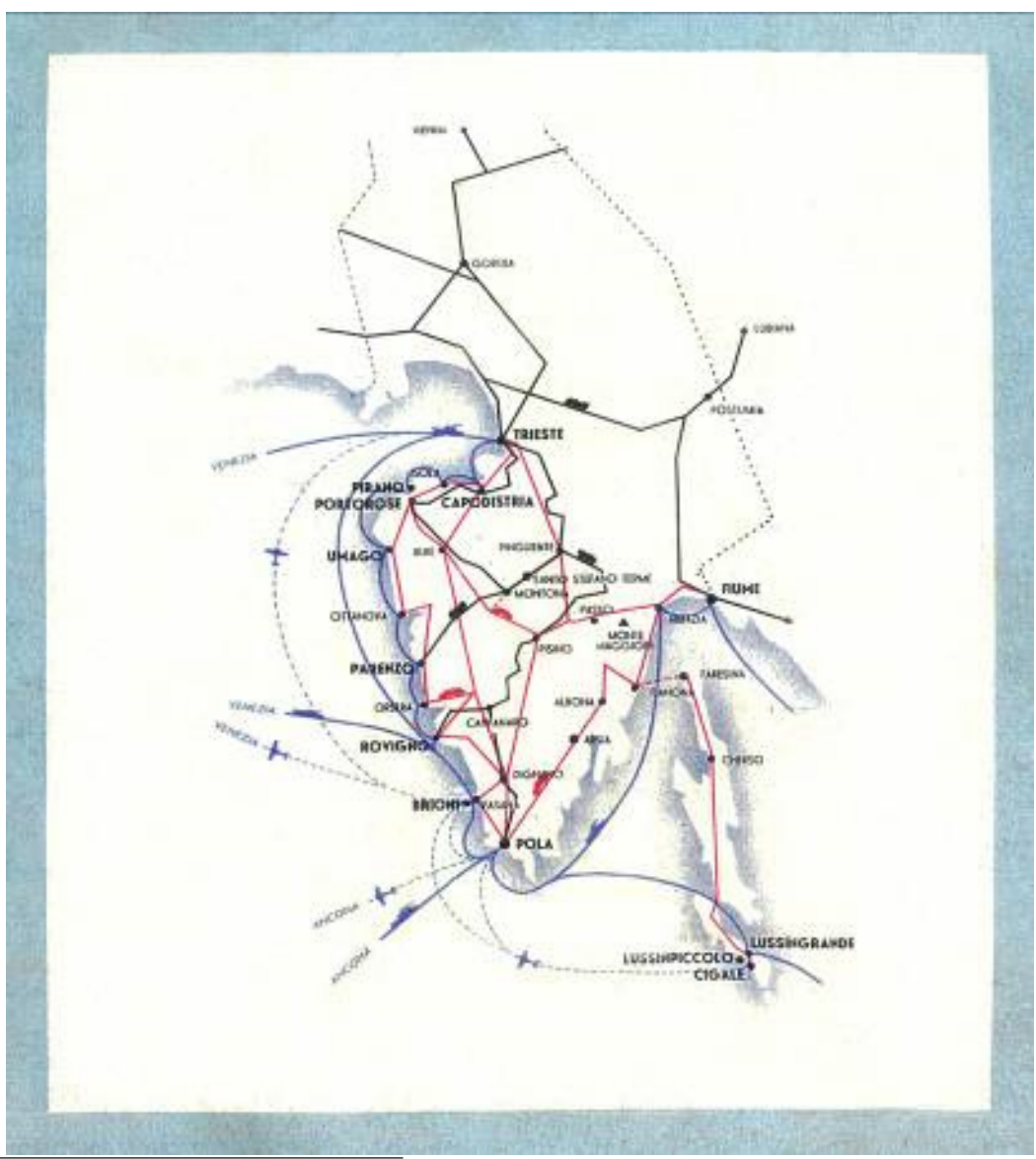

77 More about this in LAMUT, Parniki Jadrana na razglednicah, ref. 14.

78 More about this society can be found in DELISE, Ferrucio. La Società civile a Isola : documenti, statuti e regolamenti di associazioni 1597-1941. Izola: Il Mandracchio, 2011. ISBN 9789616391207. (the work is accessible on-line: http://issuu.com/iconadv/docs/libro_statuti_web_def/352\#) [cit. 2015-8-16].

79 Portorose, Thermen-Strandbäder. Pubblicazione approvata dal Ministero della Cultura popolare. Direzione Generale per il Turismo.vom provv. N.964. A. XVI. Milano; Toma: Pizzi e Pizio. Private collection of Tomi Brezovec, Portorož, Slovenia. 
In 1936 tourist associations were set up in the provinces, subsequently the Association for Tourism in the Province of Istria (Italian Ente provinciale per il turismo per la Provincia d'Istria ${ }^{80}$ was established, which coordinated the promotion of the Istrian region (Italian Provincia dell'Istria). The presentations of the northern Istrian towns are very similar to the descriptions in the older guidebooks as they were copied or revised. Minor variations occur in the current data of transport links, accommodation and other facilities.

In order to encourage travel and tourism development various promotional activities were undertaken including discounts for tourists. From 1926 the Italian State Railway in cooperation with different ministries offered $50 \%$ discount to foreign visitors to the Northern Adriatic. There was a special railway discount for families travelling to the sea resorts, spas and climatic centres during the period from 16 May to 15 October 1932. By the decree from $1929^{81}$ the exemption from the tourist tax payment for foreign tourists in the new Italian territories was formalized. Rehar ${ }^{82}$ also notes that the (international and national) political conditions for mass influx of foreign tourists were not favourable and so few came.

The great economic depression after 1929 and infectious epidemic diseases like tuberculosis ${ }^{83}$ that severely affected Istria and its tourism were also limiting factors. It is also significant that the mass exodus of the non-Italian local population as well as assimilation pressures and violence of the fascist regime ${ }^{84}$ had long-term consequences on tourism. However, it cannot be concluded that the Italian fascist authorities completely ignored this area in terms of tourism. An additional argument that confirms this claim is the asphalt paving of the road

80 BLAŽEVIĆ, Povijest turizma Istre i Kvarnera, ref. 4, p. 191, 249.

81 BLAŽEVIĆ, Povijest turizma Istre i Kvarnera, ref. 4, p. 205, 216, 228; Benvenuto/Willkomen/ Bienveu/Welcome! Trieste: Provinciale per il Turismo, Trieste \& Edizione Luglio, 1937.

82 REHAR, Nastanek in razvoj turizma ob slovenski obali, ref. 12, p. 175.

83 More about this in ŠKROBONJA, Anton (Ed.). Epidemične bolezni v Istri v 19. in 20. Stoletju / Le malattie epidemiche in Istria tra,800 e,900 / Zarazne bolesti u Istri tijekom 19. $i$ 20. Stoljeća / prispevki s študijskega dneva / relazioni della giornata di studio, Izola - Isola, 6-10-2009. Koper/Capodistria: Histria Editiones, 2010, p. 191. ISBN 9789619223574; SVOLJŠAK, Petra (Ed.). Istra u velikom ratu / L'Istria nella grande guerra / Istra v veliki vojni / Glad, bolesti, smrt / Fame, malattie, morte / Glad, bolezni, smrt. Koper/Capodistria: Histria Editiones, 2017, p. 309. ISBN 9789617007039.

84 DUKOVSKI, Darko. Dva egzodusa: hrvatski (1919-1941.) i talijanski (1943-1955). In Adrias, 2008, No. 15. ISSN 1848-7807; LEŠNIK, Avgust. Položaj slovenske ljudske šole v Istri od italijanske okupacije do osvoboditve (1918-1945). In Kronika, 1990, No. 38, p. 159-163. ISSN 0023-4923; KOSMAČ, Miha. Politično nasilje in antifašistično delovanje v Julijski krajini 1927-1931. In Acta Histriae, 2014, Vol. 24, No. 4, p. 801-818. ISSN 1318-0185. More about exodus of Slavic people can be found in ŽERJAVIĆ, Vladimir. Doseljavanja i iseljavanja s područja Istre, Rijeke i Zadra u razdoblju 1910-1971. In Društvena istraživanja, 1993, Vol. 2, No. 4-5/6-7, p. 631-656. ISSN 1848-6096. 
Trieste - Koper/Capodistria in January 1939 and later the same year the road to Portorož/Portorose, ${ }^{85}$ which was of great importance for the development of tourism in northern Istria.

Portorož/Portorose was the main tourist centre of northern Istria until the beginning of WWII, although there were a few small hotels and accommodation facilities in the area of Izola, Koper/Capodistria, Ankaran/Ancarano, Savudrija/ Salvore and Umag/Umago (these towns were slower on tourism development). At this time, Portorož/Portorose won recognition as a centre of business tourism. Thus, Portorož/Portorose hosted a national congress for 500 Italian engineers in 1935; the participants visited Buzet and got acquainted with the capacity of the source of the Mirna river. ${ }^{86}$

The economic importance of tourism concentrated in the coastal area shows the fact that tourism and hospitality in 1941 still presented the second strongest economic sector and provided $20 \%$ of the GNP of this area. WWII changed that dramatically and the tourism business was difficult to carry on ${ }^{87}$ Unlike WWI, fighting against the Nazi-fascist authorities took place also in Istria. Thus, the tourism infrastructure and superstructure had been severely affected. ${ }^{88}$

\section{Conclusion}

Since the very beginning, tourism has been one of the main industries of the northern Adriatic and the paper presents the changes through time. Closeness of the potential customers, the development of transport infrastructure, accessible, affordable and faster railway and shipping connections in the second half of the 19th century present the main factors for the development of modern tourism (also elite tourism) in this part of the Adriatic Coast. Affordable ticket prices enabled people to travel and discover new destinations with the help of objective printed guidebooks. The first guidebooks that largely replaced the subjective travelogue already contained general information about the destination, practical travel advice, presentations of towns and their offer (accommodation, food, sightseeing, architecture, excursions ...) and the vocabulary for basic communication. One of the main motives for travelling to the Adriatic coast in the AustroHungarian Monarchy was the constant longing and strong desire for sunshine

85 BLAŽEVIĆ, Povijest turizma Istre i Kvarnera, ref. 4, p. 262.

86 BLAŽEVIĆ, Povijest turizma Istre i Kvarnera, ref. 4, p. 247.

87 ROGOZNICA, Deborah. Obnova in razvoj turizma na območju cone B Svobodnega tržaškega ozemlja (s posebnim poudarkom na okraju Koper). In Acta Histriae, 2005, Vol. 13, No. 2 , p. 395-422. ISSN 1318-0185.

88 More about this in PAVLIČ, Promet in turizem, ref. 36, p. 428. 
and the blue sky. The slogan Let's go to the Adriatic! (Germ. Auf zur Adria!) indicates the popularity of the Österreichisches Küstenland (Austrian Littoral), especially the coastal area, as a tourist destination. The slogans that accompanied the beginning of every (organized) trip, such as »Ladies and gentlemen, all aboard!«, »Signori, si parte! « in Italian, and »Meine Damen und Herren, alle an Bord!« in German echoed not only in Trieste but also in the other northern Adriatic tourist resorts at that time.

In the first printed guidebooks, the coastal towns are described from the seaside, since excursionists travelled mostly by ship. The exception was Portorož/ Portorose. Due to its natural characteristics (location, healing effects of the saltpans on various diseases) it addressed guests for longer stays and therefore the information was more extensive. When the sea transport was partly replaced by the railway line between Trieste and Poreč/Parenzo, the tourist offer expanded. The opening of the railway line Vienna - Trieste certainly had much greater impact.

The automobile boom opened new possibilities and perspectives for the holidaymakers which significantly affect the content, structure and length of the guidebooks. The printed guidebook cannot be understood only as a comprehensive source of authoritative and objective information to the tourist/traveller, but also as outstanding witnesses of the time that follow the changes of travel behaviour and trends, thus reflecting the wider socio-political and economic conditions of a certain tourist destination (tourist centre, region or country). In this context, they served as an outstanding (original) source in our research.

The two world wars, different political dominations and economic fluctuations since the beginning of modern tourism in the second half of the 19th century and the first half of the 20th century significantly influenced the development of tourism in northern Istria. Each government left its mark, although it must be recognized that the frameworks outlined under the Austro-Hungarian Monarchy still exist today. For example, the Palace Hotel in Portorož/Portorose that was built in the first decade of the 20th century is still the main tourist and cultural-historical attraction of Portorož/Portorose. Not all the subsequent government changes had a positive affect on tourism development. Thus, during the period of the Kingdom of Italy between the world wars tourism did not achieve the breakthrough that had been seen before WWI. The extremely negative consequences of the fascist regime for the non-Italian population ${ }^{89}$ still nowadays

89 DIKLIĆ, Zadar i Rapallski ugovor (Uz 90. obljetnicu), ref. 54, p. 233-234; DUKOVSKI, Dva egzodusa: hrvatski (1919-1941) i talijanski (1943-1955), ref. 84; LEŠNIK, Položaj slovenske ljudske šole v Istri od italijanske okupacije do osvoboditve (1918-1945), ref. 84; KOSMAČ, Politično nasilje in antifašistično delovanje v Julijski krajini 1927-1931, ref. 84. 
prevent rational (professional and scientific) discussion of the achievements, offers, organization and other aspects of the interwar period tourism. However, we highlighted an important part of the significant economic development in Istria and thus filled the gaps in the knowledge of this period of history. In this sense, the relevance is not only related to the Croatian and Slovenian academic and professional sphere, but the results will also be useful for researchers from countries that had determined the tourism (economic) development in the region in the past, for example, Austria and Italy.

\section{»MEINE DAMEN UND HERREN, ALLE AN BORD!« REISEN AN DER NORDADRIA BIS ZUM ANFANG DES 2. WELTKRIEGS}

\section{METOD Š U L I G O J - LJUDMILA S I N K O V I Č}

Im Beitrag werden anhand des verfügbaren Archivmaterials, der bisherigen Recherchen anderer Autoren und gedruckten Reiseführer die Art und Weise des Reisens der lokalen Bevölkerung und Touristen sowie die Anfänge der organisierten Reisen an der Nordadria, analysiert. Das dargestellte Gebiet gehörte seit dem Wiener Kongress 1815 bis 1941 formell zu einem einheitlichen jedoch multikulturellen Raum. Der Zeitrahmen des Beitrages ist in zwei Teile gegliedert. Der erste Teil umfasst die Anfänge des Tourismus unter der habsburgischen Herrschaft Istriens (Österreichisches Küstenland genannt) nach dem Wiener Kongress bis zum 1. Weltkrieg, im zweiten Teil wird die Entwicklung des Tourismus unter der Herrschaft des Königreiches Italien bis zum 2. Weltkrieg dargestellt.

In der zweiten Hälfte des 19. Jahrhunderts beeinflusste Triest als die wichtigste Hafenstadt des Kronlandes des Kaisertums Österreich die wirtschaftliche Entwicklung der Küstenstädte im westlichen Teil Istriens wie z B. Koper, Izola, Piran. Bedeutend für die Entwicklung des Fremdenverkehrs stellte der rege und regelmäßige Dampfschiffsverkehr zwischen Triest und den Städten im Österreichischen Küstenland ursprünglich für Tagesausflügler, später aber auch für Reisende dar. Mit den schnelleren und besser zugänglichen Schiffs-, Bahn- und Straßenverkehrsverbindungen, die den Informationsfluss beschleunigten, erschienen die ersten gedruckten Reiseführer (z. B. Baedeker Südbaiern, Tirol und Salzburg, Steiermark, Kärnten, Krain und Küstenland. Handbuch für Reisende, 1876) mit detaillierten Auskünften über Geschichte des bereisten Gebietes, Natur- und Kultursehenswürdigkeiten, Beherbergungsbetriebe, Fahrpläne, Ausflugstipps, Preise für den öffentlichen Verkehr, Alltagsausdrücke in der Sprache des Reisezieles usw.

Im Beitrag werden auch die institutionelle Unterstützung der Tourismusentwicklung und die strategischen Entwicklungsaspekte der österreichisch-ungarischen und später italienischen Regierung erläutert. Die Letztere erzielte aufgrund von anti-slawischen 
Bewegungen, anderen politischen Umständen, der Wirtschaftskrise und der Ausbreitung der epidemischen Krankheiten deutlich niedrigere Ergebnisse im istrischen Tourismus.

Metod Šuligoj, PhD

University of Primorska, Faculty of tourism studies - Turistica Obala 11a, Portorož-Portorose, Slovenia e-mail: Metod.suligoj@fts.upr.si

Ljudmila Sinkovič

University of Primorska, Faculty of tourism studies - Turistica Obala 11a, Portorož-Portorose, Slovenia e-mail: Ljudmila.sinkovic@ fts.upr.si 